\title{
CORRIGENDUM
}

\section{mTORC1-dependent translation of collapsin response mediator protein-2 drives neuroadaptations underlying excessive alcohol-drinking behaviors}

F Liu, S Laguesse, R Legastelois, N Morisot, S Ben Hamida and D Ron

Molecular Psychiatry (2018) 23, 164; doi:10.1038/mp.2017.252; published online 14 November 2017

Correction to: Molecular Psychiatry (2017) 22: 89-101; doi: 10.1038/mp.2016.12

The Supplementary Figures for this paper were omitted when it was published. The complete version of the Supplementary Materials accompanies this corrigendum.

\begin{abstract}
(2) This work is licensed under a Creative Commons AttributionBY NG SA NonCommercial-ShareAlike 4.0 International License. The images or other third party material in this article are included in the article's Creative Commons license, unless indicated otherwise in the credit line; if the material is not included under the Creative Commons license, users will need to obtain permission from the license holder to reproduce the material. To view a copy of this license, visit http:// creativecommons.org/licenses/by-nc-sa/4.0/
\end{abstract}

(c) The Author(s) 2018

Supplementary Information accompanies the paper on the Molecular Psychiatry website (http://www.nature.com/mp) 